\title{
UNDERWEIGHT AND SLIMNESS AND THEIR RELATION TO Dietary Habits aNo blOOd Pressure among SaUdI FEMALE STUDENTS IN TAIBAH UNIVERSITY
}

\author{
By \\ Afaf Hamza Basheer Amer \\ Eman Sobhy Taha Attia \\ Food Science Dept., Faculty of Family Food Science Dept., Faculty of Family \\ Sciences, Taibah University, KSA. Sciences, Taibah University, KSA \\ National Nutrition Institute (NNI), \\ Cairo.
}

Research Gournal Specific Fducation

Faculty of Specific Fducation

glansoura University

ISSUE NO. 34, MAY. 2014

مجلة بحوث التربية النوعية ـ جامعة المنصورة

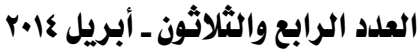




\title{
UNDERWEIGHT AND SLIMNESS AND THEIR RELATION TO DIETARY Habits aNd BlOOd PRESSURE AMONG SAUdI FEMALE STUDENTS IN TAIBAH UNIVERSITY
}

\author{
Afaf Hamza Basheer Amer
}

\author{
Eman Sobhy Taha Attia
}

\begin{abstract}
Background: Underweight is a term describing a human whose body weight is considered too low to be healthy. Underweight is associated with negative health consequences, such as nutritional deficiency, osteoporosis, and unfavorable pregnancy outcomes in women of childbearing age. Several studies were carried out in Saudi Arabia to study the prevalence of overweight or obesity among women, and ignored underweight. Objective: This study was designed to find out the prevalence of underweight and slimness among young Saudi female students and describes its relation with dietary habits, blood pressure and socio-demographic differentials. Methodology: This study was carried out on 220 female students aged 18 to 24 years were chosen from, Taibah University., Al Madinah Al Munawwarah, KSA, then classified according to BMI into fifth categories; Very severely underweight $(<15 \mathrm{~kg} / \mathrm{m} 2)$; severely underweight (15 to 16 $\mathrm{kg} / \mathrm{m} 2$ ); underweight (16 to $18.5 \mathrm{~kg} / \mathrm{m} 2$ ); normal weight (18.5 to $25 \mathrm{~kg} / \mathrm{m} 2$ ); and overweight $(>25 \mathrm{~kg} / \mathrm{m} 2)$. All normal, obese, and overweight girls were excluded from the study that carried out on underweight girls (150 females). Data socioeconomic status, health history, dietary habits, anthropometric measurements, and blood pressure measurement were collected. Results: the result showed that $3.2 \%$ of studied girls were suffering from very severely underweight, $5.9 \%$ were severely underweight, while the most of girls were underweight $59.1 \%, 19.5 \%$ had normal weight and $12.3 \%$ were overweight. Most of girls $97.3 \%$ of them were age between $18-24$ years, also $42 \%$ of

* Food Science Dept., Faculty of Family Sciences, Taibah University, KSA.

Food Science Dept., Faculty of Family Sciences, Taibah University, KSA - National Nutrition Institute (NNI), Cairo.
\end{abstract}


girls were in the second academic year and $85.3 \%$ of girls were single. While most of girls $79.3 \%$ were no suffering from diseases, while about $20.7 \%$ of girls were suffering from diseases including; anemia, tuberculosis, diabetes mellitus and osteoporosis. On the other hand $70 \%$ of subjects were desired systolic BP $(90-119 \mathrm{mmHg})$ and also $72 \%$ of subjects were desired diastolic BP $(60-79 \mathrm{mmHg})$. As for bad dietary habits were like eating one meal per day, not $r$ eating breakfast, use traditional method (Mesabek) in cooking and low rates of milk consumption, meat and fruits and vegetables daily. In conclusion: High percentage of females suffering from underweight, most of them were from low socioeconomic class, and they have some bad food habits that may worsen their status and could be at risk for deficiencies of essential nutrients, also blood pressure measurements of girls were at normal ranges. This study recommended promotion of health eating, habits and physical activity.

Key word: Underweight, slimness, blood pressure, dietary habits, body mass index, university, Saudi female students.

Corresponding author: drafaf@ hotmail.com

\section{INTRODUCTION}

Although Saudi Arabia has high food availability, yet some degree of malnutrition and diet related chronic diseases are prevalent. The recent rapid changes in lifestyle and dietary habits have led to great changes in dietary pattern. (Khan, 2012). Some degree of malnutrition in pre-school children and increasing trends in diet-related chronic diseases in other population groups due to imbalance of diet; sedentary lifestyle and ignorance have been reported (Katzmarzyk and Jenssen, 2004).

Like overweight or obesity that known to be associated with an increased risk of chronic diseases such as; type 2 diabetes, hypertension, menstrual abnormalities, psychosocial dysfunction, cardiovascular disease, arthritis, Pickwickian syndrome, gout, gallbladder disease, digestive disease, cancer, respiratory dysfunction, diverticular disease, various skin conditions, and overall mortality. (Wilson et al., 2002; Calle and Thun, 2004). Of these conditions, hypertension may be the most closely linked to obesity, and its 
prevalence appears to increase as the prevalence of obesity increase (Jee et al., 2006). Obese subjects are at an increased risk of becoming risk of becoming hypertensive and several studies have shown a significantly higher prevalence of hypertension in obese individuals (Dustan , 1991; Staessen et al., 1998). This has a special implication as it predisposes to cardiovascular damage and atherogenic cardiovascular diseases (Kannel, 2000 ; Licata et al., 1999). Hence obesity is a major risk factor for hypertension, that itself is a direct cause of premature cardiovascular morbidity and mortality. (Dustan, 1991; Mikhail et al., 1999). In an extensive investigation conducted in different regions of Saudi Arabia we observed that $13 \%$ of Saudi females were in the obese groups with a body mass index (BMI) of 30 or more (El-Hamzmi and Warsy, 1997).

Underweight is a term describing a human whose body weight is considered too low to be healthy. The definition usually refers to people with a body (BMI) of less than 18.5 (National Heart, Lung and Blood Institute, 2012) or a weight $15 \%$ to $20 \%$ below that normal for their age and height group (Mahan, 2000). Underweight is also associated with negative health consequences, such as nutritional deficiency, osteoporosis, and unfavorable pregnancy outcomes in women of childbearing age. As in obesity, underweight is also an important risk factor to increased mortality risk (Tsugane et al., 2002). It seems that the high prevalence of overweight and obesity resulted in a change in the concept of an ideal body image from the overweight female to that of the slim figure especially with advancing education (Iman, 2007).

Underweight and unintentional weight loss can be caused by; an intake insufficient in quantity to meet activity needs; excessive activity such as in the case of compulsive athletes in training; poor absorption and metabolism of the consumed; a wasting disease such as cancer or hyperthyroidism that increases the metabolic rate and energy needs; and psychological or emotional stress (Mahan and Escott-Stump, 2008; Hays, 2006). Malnutrition contributes to approximately $60 \%$ of the child death. Despite the obvious impact of malnutrition on global health, it does capture the attention of policy-makers and lacks appropriate resources (WHO, 2006). 
Many studies were carried out on Saudi population to find out the prevalence of obesity and overweight; one epidemiological study (AlNuaim et al., 2012) found that obesity was prevalent among $19.1 \%$ of males and $17.7 \%$ of females. Al-Othaimeen et al., (2007) found that obesity was prevalent among $14.2 \%$ of males and $23.6 \%$ of females. A study carried out. Moreover Musaigar (2004) in his review article mentioned that the prevalence of obesity among unemployed women in Saudi Arabia was 79\% and 53\% among employed women.

Most of studies carried out in Saudi Arabia studied overweight or obesity among women, and ignored underweight. While studies regarding desire for slimness in young women are form Western societies. Therefore and in accordance with the result of other studies, the objective of the present study was find out the prevalence of underweight and slimness among young Saudi female students and describe its relation with dietary habits and blood pressure.

\section{AIM OF STUDY}

The study was aimed to find out the prevalence of underweight and slimness among Saudi female students and its relation with dietary habits and blood pressure.

\section{SUBJECTS AND METHODS}

This study was carried out on 220 female students chosen from food science department of College of Family Sciences for Girls, Taibah University., Al Madinah Al Munawwarah, KSA.

\section{Experimental Design:}

Body weights and heights were measured and BMI were calculated. The students were classified according to BMI into fifth categories; Very severely underweight $(<15 \mathrm{~kg} / \mathrm{m} 2)$; severely underweight $(15$ to $16 \mathrm{~kg} / \mathrm{m} 2)$; underweight (16 to $18.5 \mathrm{~kg} / \mathrm{m} 2$ ); normal weight (18.5 to $25 \mathrm{~kg} / \mathrm{m} 2)$; and overweight $(>25 \mathrm{~kg} / \mathrm{m} 2)$. All normal, obese, and overweight girls were excluded from the study that carried out on underweight girls (150 females). 


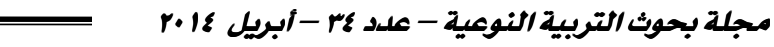

\section{Data Collection:}

Data were collected using self-administered questionnaire consisting of socio-demographic, health history, and dietary habits, anthropometric and blood pressure measurements.

\subsection{Socioeconomic Status:}

Data about age, academic year, marital status, family income and family size were done according to Park and Park, (1979).

\subsection{Health History:}

Data include current health status of subjects and their parents, Activity in thyroid gland, Nervous and Psychological stress, Dizziness and Vertigo, Anorexia and Causes of Anorexia.

\subsection{Dietary Habits:}

Data about number of meals, eating breakfast, places of eating it, preferred foods and cooking method and some food items consumptions were collected.

\section{Anthropometric Measurements:}

Weight and height were measured with the subjects wearing light clothing, without shoes and recorded to the nearest $0.1 \mathrm{~kg}$, and $0.1 \mathrm{~cm}$, respectively. Arm circumference was recorded according to (Kuczmarski et al., 2000).

Body mass index (BMI) was determined based upon the established World Health Organization (WHO 1995) international anthropometrical references. Very severely underweight is defined as BMI $<15 \mathrm{~kg} / \mathrm{m} 2$ severely underweight BMI ranges from 15 to less than $16 \mathrm{~kg} / \mathrm{m} 2$.

Underweight is considered between 16 to less than $18.5 \mathrm{~kg} / \mathrm{m} 2$ According to (Bellizzi and Dietz, 1999).

\section{Blood pressure Measurement:}

Blood pressure was measured using a sphygmomanometer according to Booth, 1977. Blood pressure values were recorded as Systolic and Diastolic pressure in millimetres of mercury $\mathrm{mmHg}$. Blood pressures were categorized into three groups; low (hypotension) values $<90 / 60$ or lower, 
normal (desired) values above 90/60 and below 130/80 (Prehypertension), and high (hypertension) values 140/90 or higher (Chobanian et al., 2003; American Heart Association, 2011).

\section{Statistical Analysis:}

Data were analyzed using statistical for social science (SPSS) program, version 16.0. (SPSS, 1998).

\section{RESULTS}

Based on BMI classification, table (1) showed that distribution of studied sample, 7 (3.2\%) of studied girls were suffering from very severely underweight, and 13 (5.9\%) suffered from severely underweight, while the most of girls were suffered from underweight 130 (59.1\%), and 43 (19.5\%) had normal weight, finally $27(12.3 \%)$ suffered from overweight. As mentioned previously all girls with normal and overweight were excluded from the study.

Table (2) shows demographic characteristic of the study sample, the total number of study participants amounted to 150 females; most of them were enrolled at the second education year $42 \%$ with mean age of $20.46 \pm$ 2.38 years. The majority of students were single, 128 (85.3\%), while the married students were $22(14.7 \%)$. As for number of children for married students, about 7 (31.8\%) of students no had children, whereas $8(36.3 \%)$ of the married students had one children, also about 4 (18.2\%) of the married students had two children, and about 3 (13.7\%) of the married students had more than three children. Moreover, about 15 (10\%) of students had family income less than 3000 Saudi Riyal, while the majority of students had family income between 5000 to 7000 SR ,101 (67.3\%), only 34 (22.4\%) of the girls had family income more than 7000 SR.

Table (3) demonstrates Anthropometric measurements of the study sample, the majority of students were recorded weights between 35 to 45 $\mathrm{kg}, 118(78.6 \%)$, and about $4(2.7 \%)$ of the students were less than $35 \mathrm{~kg}$, while $28(18.7 \%)$ of the students were more than $45 \mathrm{~kg}$, with mean value of weight $42.20 \pm 4.10 \mathrm{~kg}$ for all study sample. On the other hand, the most of students were recorded height more than $155 \mathrm{~cm}, 103(68.7 \%)$, and 44 
$(29.3 \%)$ of them were between 145 to $155 \mathrm{~cm}$, and few subjects were recorded less than $145 \mathrm{~cm}, 3(2 \%)$, with mean value of height $157.50 \pm 6.10$ $\mathrm{cm}$ for all study sample. As for arm circumference, the most of students were recorded between 20 to $25 \mathrm{~cm} 124(82.7 \%)$, and 20 (13.3\%) of the girls were less than $20 \mathrm{~cm}$, while a few subjects were more than $25 \mathrm{~cm} 6$ (4\%), with mean value of arm circumference $21.94 \pm 2.19 \mathrm{~cm}$ for all study sample.

Table (4) demonstrates blood pressure measurements of the study sample, the majority of students were recorded normal values of systolic BP between 90 to $119 \mathrm{mmHg}, 105$ (70\%), and about $15(10 \%)$ of the students were suffering from hypotension, less than $90 \mathrm{mmHg}$, while 30 (20\%) of the students were between 120 to $139 \mathrm{mmHg}$ as hypertension, with mean value of systolic BP $112.70 \pm 11.97 \mathrm{mmHg}$ for all study sample On the other hand, , the majority of students were recorded normal values of diastolic BP between 60 to $79 \mathrm{mmHg}, 108$ (72\%), and about $34(22.7 \%)$ of the students were suffering from hypertension between 80 to $89 \mathrm{mmHg}$, while $8(5.3 \%)$ of the students were less than $60 \mathrm{mmHg}$ as hypotension, with mean value of systolic BP $74.65 \pm 10.67 \mathrm{mmHg}$ for all study sample.

Table (5) shows health history of the study sample, the total number of study participants amounted to 150 females; most of them were not suffering from diseases 119 (79.3\%), while about 31(20.7\%) of girls were suffering from diseases most of them were suffering from anemia 16 $(51.6 \%)$, and $4(12.9 \%)$ of them suffering from tuberculosis, and $3(9.6 \%)$ of them suffering from Diabetes mellitus and colon, while 5 (16.1\%) of them suffering from others disease include; peptic ulcer, osteoporosis skin diseases. As for activity in thyroid gland, the most of girls did not have activity in thyroid gland 137 (91.3\%), while 13 (8.7\%) of them suffering from activity in gland. On the other hand, the students were characterized in mood nervous recorded 81 (54\%), and about 69 (46\%) of the students were not nervous.

The same table also illustrates, the majority of girls were not suffering from psychological stress 106 (70.7\%), while 44 (29.3\%) of girls suffering 
from that. The subjects were suffering from dizziness and vertigo, 85 (56.7\%), and about 44 (29.3\%) of subjects were not suffering from that. The majority of girls were feeling dizziness and vertigo during waking and effort, 31 (36.4\%), also $11(12.9 \%)$ of them were feeling dizziness and vertigo during hunger, while $21(24.7 \%)$ of them were this feeling during other include; exercise and the menstrual cycle. As for anorexia, the most of girls were suffering from anorexia (lack of appetite) 116 (77.3\%), while 34 (22.7\%) of them were not suffering from that. Regarding causes of anorexia, the majority of girls were not feeling hungry $42(36.2 \%)$ and about 33 (28.4\%) of them did not eating because busyness, while $16(13.7 \%)$ of them because of sleep and laziness, finally $33(28.4 \%)$ of them did not eating because others factors include; stress, lack of knowledge and anxiety. It could be noticed from table (5) that the majority of girl's parents were suffering from underweight and slimness 95 (63.3\%), while about 55 (36.7\%) of a girl's parents were not suffering from that.

Table (6) dietary habits of the study sample, the majority of girls reported eating two meals daily 89 (59.3\%), and about 55 (36.7\%) of them reported eating three meals daily, while $6(4 \%)$ of students reported eating one meal per day. It is clear from table (6) the majority of girls reported eating breakfast $105(70 \%)$, and about $45(30 \%)$ of them did not reported eating breakfast. On the other hand $47(44.7 \%)$ of girls reported eating breakfast at home, while $58(55.3 \%)$ of them reported eating breakfast at college. Regarding preferred foods, the majority of girls were preferred sweet foods $84(56 \%)$, while about $66(44 \%)$ of them were preferred salty foods. As for preferred cooking method, the majority of subjects were preferred traditional method (Mesabek) 47 (31.3\%), while about 25 (16.7\%) of them were preferred boiled or stir-fried methods, and 35 (23.3\%) of the girls were preferred grilled method, finally $43(28.7 \%)$ of them preferred baking method.

Table (7) consumption of different food item of the study sample, the majority of girls reported drinking milk $121(80.7 \%)$, and about $29(19.3 \%)$ of them did not reported drinking milk. On the other hand $138(44.7 \%)$ of girls reported eating meat, while $12(8 \%)$ of them did not reported eating 
meat. Also the most of students reported eating fruits and vegetables 147 (98\%), while about $3(2 \%)$ of them did not reported eating fruits and vegetables.

Frequency of eating different food item is presented in table (8). The present sample demonstrated consumption of milk, meat and fruits and vegetables once daily were, 28 (23.1\%), 25 (18.1) \% and 34 (22.9\%) respectively. While the present sample reported consumption of milk, meat and fruits and vegetables twice or more per day were, 3(2.4\%), $1(0.72 \%)$ and $25(16.9 \%)$ respectively. Also the students reported consumption of milk, meat and fruits and vegetables Once weekly were, 53(43.9\%), 21 $(15.2 \%)$ and $15(10.1 \%)$ respectively. While the subjects demonstrated consumption of milk, meat and fruits and vegetables twice per week were, $27(22.4 \%), 56(40.6 \%)$ and $29(19.6 \%)$ respectively. Finally the subjects reported consumption of milk, meat and fruits and vegetables Three times per week were, $10(8.2 \%), 35(25.4 \%)$ and $45(30.5 \%)$ respectively.

\section{DISCUSSION}

The results indicated that $59.1 \%$ of girls were underweight and $12.3 \%$ of girls were overweight, this percentage nearly with Iman, (2007) who observed that $43 \%$ of students girls suffered from underweight and $19 \%$ of them were overweight, although this percentage seemed higher than other Saudi studies Abalkhail et al., (2002), but it revealed the common attitude of the university girls, where most of them try avoid obesity and its complications. This observation primarily observed by Al Bedwee et al., (2004) who observed that the Tunisian university girls tend to be thin. Moreover, most of studied subjects were studying nutrition and know how to limit their intake from high calorie foods. This result emphasis the concepts of Rasheed (1998) who observed that a change in the concept of an ideal body image from the overweight female to that of the slim figure accompanied advancing education. In conclusion, women with higher educational level were more likely to favor slimness as an ideal.

Most of girls $97.3 \%$ of them were age between $18-24$ years, also $42 \%$ of girls were in the second academic year and $85.3 \%$ of girls were 
single, this results agreed with Iman (2007), who observed that married subjects of university girls were heavier than the unmarried subjects.

It could be concluded from table (4) that most of subjects $70 \%$ of them were desired systolic BP $(90-119 \mathrm{mmHg})$ and also $72 \%$ of subjects were desired diastolic BP $(60-79 \mathrm{mmHg})$ this results agreed with El-Hazmi and Arjumand, (2001) who were confirmed that the non-obese males and females the prevalence of hypertension was $4.8 \%$ and $2.8 \%$. While in the obese group the prevalence was almost 1.6 times higher in the males $(8 \%)$ and 3.52 times higher (8\%) in the female obese. Obesity and hypertension are closely associated multifactorial disorders and studies in different population groups have confirmed that the prevalence of hypertension increases significantly in the obese (Kastarinen et al., 2000, Mikhail et al., 1999), also who were e observed that the prevalence of hypertension is higher in the obese than the non-obese and the prevalence in the obese females is more than the obese males in the Saudi population. Also it can be observed from table (9) the correlation matrix between blood pressure and anthropometric measurements, there were no significant differences between systolic BP, diastolic BP and body mass index and weight.

Most of girls $79.3 \%$ were no suffering from diseases, while about $20.7 \%$ of girls were suffering from diseases including; anemia, tuberculosis, diabetes mellitus and osteoporosis Tsugane et al., (2002) who reported that underweight is associated with negative health consequences, such as nutritional deficiency, depression are moodiness, tiredness, an overpowering urge to sleep all day, inability to do simple daily tasks. Also $63.3 \%$ of girl's parents were suffering from underweight and slimness this results supported with Mahan and Escott-Stump (2008) who reported that underweight can be caused by genetic and heredity factors.

It could be concluded from Table (6) that bad dietary habits like eating one meal per day, not $r$ eating breakfast, use traditional method (Mesabek) in cooking and low rates of milk consumption, meat and fruits and vegetables once daily, also Iman (2007) reported that food habits like eating cafeteria food daily drinking tea after meals directly, and drinking coffee 
before breakfast were more prevalent among underweight, while normal subjects share or exceed them in other bad food habits. However, the increasing westernization and urbanization occurring in most countries around the world is associated with changes in the dietary habits and types of consumed foods and drinks. This bad food habits were prevalent among adolescents and young adults in the Gulf area.

The nutritional problems in Saudi Arabia are mainly due to a change in food habits, illiteracy and ignorance, rather than a shortage of food supply or low income. Therefore, it is essential for all people to eat a balanced diet which will provide the dietary requirements of all nutrients. Perhaps behavior modification with respect to food intake will be effective in the treatment of underweight (Simopoulos, 1985).

\section{CONCLUSION}

The combined prevalence of underweight and slimness among Saudi female students is increasing and comparable to those found in the developed countries. Less healthy dietary habits, poor food choices and socio-economic differentials may be associated with the problem of underweight and slimness including Saudi Female Students in Taibah University.

\section{RECOMMENDATIONS}

Those involved in underweight prevention may use these findings to implements university- based food programs and nutritional health education messages with incorporation of skills for proper food choices. Emphasizing the importance of breakfast, and the hazards of frequent eating out and the importance of certain food items in prevention of underweight to girls. Further studies involving females and other possible risk factors of underweight are needed. 
Table (1): Distribution of the study sample $(n=220)$ according to BMI

\begin{tabular}{||l|c|c|}
\hline Body mass index BMI classification $(\mathrm{kg} / \mathrm{m} 2)$ & NO. & $\%$ \\
\hline \hline Very severely underweight $(<15)$ & 7 & 3.2 \\
\hline Severely underweight $(15-16)$ & 13 & 5.9 \\
\hline Underweight $(>16-18.5)$ & 130 & 59.1 \\
\hline Normal weight $(>18.5-25)$ & 43 & 19.5 \\
\hline Overweight $(>25)$ & 27 & 12.3 \\
\hline Total & 220 & 100 \\
\hline
\end{tabular}

Table (2): Demographic characteristic of the study sample $(\mathrm{n}=150)$

\begin{tabular}{|c|c|c|}
\hline Variables & NO. & $\%$ \\
\hline Age groups (years) & \multicolumn{2}{|c|}{ Mean $\pm \mathrm{SD}=20.46 \pm 2.38$} \\
\hline $18-24$ & 146 & 97.3 \\
\hline$>24$ & 4 & 2.7 \\
\hline Total & 150 & 100 \\
\hline \multicolumn{3}{|c|}{ Academic year } \\
\hline First year & 45 & 30 \\
\hline Second year & 63 & 42 \\
\hline Third year & 24 & 18 \\
\hline Fourth year & 15 & 10 \\
\hline Total & 150 & 100 \\
\hline \multicolumn{3}{|c|}{ Marital status } \\
\hline Single & 128 & 85.3 \\
\hline Married & 22 & 14.7 \\
\hline Total & 150 & 100 \\
\hline \multicolumn{3}{|c|}{ Number of children } \\
\hline No & 7 & 31.8 \\
\hline One child & 8 & 36.3 \\
\hline Two children & 4 & 18.2 \\
\hline$>3$ children & 3 & 13.7 \\
\hline Total & 22 & 100 \\
\hline \multicolumn{3}{|c|}{ Family income (SR) } \\
\hline Low $(<3000)$ & 15 & 10 \\
\hline Medium $(5000-7000)$ & 101 & 67.3 \\
\hline $\operatorname{High}(>7000)$ & 34 & 22.7 \\
\hline Total & 150 & 100 \\
\hline
\end{tabular}


Table (3): Anthropometric measurements of the study sample $(\mathrm{n}=150)$

\begin{tabular}{||c|c|c|}
\hline Variables & NO. & $\%$ \\
\hline \hline Weight groups (kg) Mean $\pm \mathrm{SD}=42.20 \pm 4.10 \mathrm{~kg}$ & \\
\hline$<35$ & 4 & 2.7 \\
\hline $35-45$ & 118 & 78.6 \\
\hline$>45$ & 28 & 18.7 \\
\hline Total & 150 & 100 \\
\hline$<145$ & 3 & 2 \\
\hline Height groups (cm) Mean $\pm \mathrm{SD}=157.50 \pm 6.10 \mathrm{~cm}$ & 29.3 \\
\hline $145-155$ & 44 & 68.7 \\
\hline$>155$ & 103 & 100 \\
\hline Total & 150 & 13.3 \\
\hline Arm Circumference groups (cm) Mean $\pm \mathrm{SD}=21.94 \pm 2.19 \mathrm{~cm}$ \\
\hline$<20$ & 20 & 82.7 \\
\hline $20-25$ & 124 & 4 \\
\hline$>25$ & 6 & 100 \\
\hline Total & 150 & \\
\hline
\end{tabular}

Table (4): Blood pressure measurements of the study sample $(\mathrm{n}=150)$

\begin{tabular}{||c|c|c|}
\hline Blood pressure classification & NO. & $\%$ \\
\hline \hline \multicolumn{1}{|c|}{ Systolic BP (mmHg) Mean $\pm \mathrm{SD}=112.70 \pm 11.97$} \\
\hline Hypotension $(<90)$ & 15 & 10 \\
\hline Desired $(90-119)$ & 105 & 70 \\
\hline Prehypertension $(120-139)$ & 30 & 20 \\
\hline Total & 150 & 100 \\
\hline Diastolic BP (mmHg) Mean $\pm \mathrm{SD}=74.65 \pm 10.67$ \\
\hline Hypotension (<60) & 8 & 5.3 \\
\hline Desired $(60-79)$ & 108 & 72 \\
\hline Prehypertension $(80-89)$ & 34 & 22.7 \\
\hline Total & 150 & 100 \\
\hline
\end{tabular}


Table (5): Health history of the study sample $(\mathrm{n}=150)$

\begin{tabular}{|c|c|c|}
\hline Variables & NO. & $\%$ \\
\hline \multicolumn{3}{|l|}{ Suffering from diseases } \\
\hline Yes & 31 & 20.7 \\
\hline No & 119 & 79.3 \\
\hline Total & 150 & 100 \\
\hline \multicolumn{3}{|l|}{ Types of disease } \\
\hline Diabetes mellitus & 3 & 9.6 \\
\hline Colon & 3 & 9.6 \\
\hline Tuberculosis & 4 & 12.9 \\
\hline Anemia & 16 & 51.6 \\
\hline Others & 5 & 16.1 \\
\hline Total & 31 & 100 \\
\hline \multicolumn{3}{|l|}{ Activity in thyroid gland } \\
\hline Yes & 13 & 8.7 \\
\hline No & 137 & 91.3 \\
\hline Total & 150 & 100 \\
\hline \multicolumn{3}{|l|}{ Nervous } \\
\hline Yes & 81 & 54 \\
\hline No & 69 & 46 \\
\hline Total & 150 & 100 \\
\hline \multicolumn{3}{|l|}{ Psychological stress } \\
\hline Yes & 44 & 29.3 \\
\hline No & 106 & 70.7 \\
\hline Total & 150 & 100 \\
\hline \multicolumn{3}{|l|}{ Dizziness and Vertigo } \\
\hline Yes & 85 & 56.7 \\
\hline No & 65 & 43.3 \\
\hline Total & 150 & 100 \\
\hline \multicolumn{3}{|c|}{ Time of Dizziness and Vertigo } \\
\hline Waking & 31 & 36.4 \\
\hline Hunger & 11 & 12.9 \\
\hline Effort & 31 & 36.4 \\
\hline Others & 21 & 24.7 \\
\hline Total & 85 & 100 \\
\hline \multicolumn{3}{|c|}{ Anorexia (lack of appetite) } \\
\hline Yes & 116 & 77.3 \\
\hline No & 34 & 22.7 \\
\hline Total & 150 & 100 \\
\hline \multicolumn{3}{|c|}{ Causes of Anorexia (lack of appetite) } \\
\hline Not feeling hungry & 42 & 36.2 \\
\hline Busyness & 25 & 21.5 \\
\hline Sleep and laziness & 16 & 13.7 \\
\hline Others & 33 & 28.4 \\
\hline Total & 116 & 100 \\
\hline \multicolumn{3}{|c|}{ A parent suffering from underweight or slimness } \\
\hline Yes & 95 & 63.3 \\
\hline No & 55 & 36.7 \\
\hline Total & 150 & 100 \\
\hline
\end{tabular}


Table (6): Dietary habits of the study sample $(\mathrm{n}=150)$

\begin{tabular}{|c|c|c|}
\hline Variables & NO. & $\%$ \\
\hline \multicolumn{3}{|l|}{ No. of main meals / day } \\
\hline One meal & 89 & 59.3 \\
\hline Two meal & 55 & 36.7 \\
\hline Three meal & 6 & 4 \\
\hline Total & 150 & 100 \\
\hline \multicolumn{3}{|l|}{ Eating breakfast } \\
\hline Yes & 105 & 70 \\
\hline No & 45 & 30 \\
\hline Total & 150 & 100 \\
\hline \multicolumn{3}{|l|}{ Place of eating breakfast } \\
\hline At home & 47 & 44.7 \\
\hline At college & 58 & 55.3 \\
\hline Total & 105 & 100 \\
\hline \multicolumn{3}{|l|}{ Preferred foods } \\
\hline Sweet foods & 84 & 56 \\
\hline Salty foods & 66 & 44 \\
\hline Total & 150 & 100 \\
\hline \multicolumn{3}{|l|}{ Preferred cooking method } \\
\hline Traditional (Mesabek) & 47 & 31.3 \\
\hline Boiled or stir-fried & 25 & 16.7 \\
\hline Grilled & 35 & 23.3 \\
\hline Baking & 43 & 28.7 \\
\hline Total & 150 & 100 \\
\hline
\end{tabular}

Table (7): Consumption of different food item of the study sample $(n=150)$

\begin{tabular}{||c|c|c|}
\hline \hline Food Items & NO. & $\%$ \\
\hline \hline Drinking milk & 121 & 80.7 \\
\hline Yes & 29 & 19.3 \\
\hline No & 150 & 100 \\
\hline Total & 138 & 92 \\
\hline Eating meat & 12 & 8 \\
\hline Yes & 150 & 100 \\
\hline No & \\
\hline Total & 147 & 98 \\
\hline Eating fruits and vegetables & 3 & 2 \\
\hline Yes & 150 & 100 \\
\hline No
\end{tabular}


Table (8): Consumption frequency of different food item of the study sample $(\mathrm{n}=150)$

\begin{tabular}{||c|c|c|c|c|c|c|c|c|c|c||}
\hline \multirow{2}{*}{ Food Items } & \multicolumn{2}{|c|}{ Once/ day } & \multicolumn{2}{c|}{$\begin{array}{c}\text { Twice or } \\
\text { more / day }\end{array}$} & \multicolumn{2}{c|}{$\begin{array}{c}\text { Once/ } \\
\text { week }\end{array}$} & \multicolumn{2}{c|}{$\begin{array}{c}\text { Twice/ } \\
\text { week }\end{array}$} & \multicolumn{2}{c|}{$\begin{array}{c}\text { Three times / } \\
\text { week }\end{array}$} \\
\cline { 2 - 13 } & No. & $\%$ & No. & $\%$ & No. & $\%$ & No. & $\%$ & No. & $\%$ \\
\hline \hline Milk & 28 & 23.1 & 3 & 2.4 & 53 & 43.9 & 27 & 22.4 & 10 & 8.2 \\
\hline Meat & 25 & 18.1 & 1 & 0.72 & 21 & 15.2 & 56 & 40.6 & 35 & 25.4 \\
\hline fruits and Vegetables & 34 & 22.9 & 25 & 16.9 & 15 & 10.1 & 29 & 19.6 & 45 & 30.5 \\
\hline
\end{tabular}

Table (9): Correlation matrix between blood pressure and anthropometric measurements

\begin{tabular}{||c|c|c|c|c|c||}
\hline $\begin{array}{c}\text { Blood } \\
\text { pressure }\end{array}$ & Correlation & Weight & Height & BMI & $\begin{array}{c}\text { Arm } \\
\text { circumference }\end{array}$ \\
\hline \hline Systolic & Pearson & -.154 & -.048 & .018 & -.140 \\
BP & correlation & .059 & .557 & .830 & .087 \\
& Sig. (2-tailed) & 150 & 150 & 150 & 150 \\
& $\mathrm{~N}$ & & & & .014 \\
\hline Distolic & Pearson & -.036 & $-.165^{*}$ & .127 & .865 \\
BP & correlation & .664 & .044 & .121 & 150 \\
& Sig. (2-tailed) & 150 & 150 & 150 & \\
& $\mathrm{~N}$ & & & & \\
\hline \hline
\end{tabular}

** correlation is significant at the 0.01 level (2-tailed).

* correlation is significant at the 0.05 level (2-tailed).

\section{REFERENCES}

- Abalkhail, B., Shawky, S, and Soliman, N. K. (2002). Validity of self-reported weight and height among Saudi school children and adolescents. Saudi Med J. 2002 Jul; 23 (7): 831-7.

- Al Bedwee, A., Laila, A. and Omrani, A. (2004). Nutritional disturbances of university Tunisian girls . Arabs J. Food and Nutr. 5 (11): 199- 202.

- Al-Nuaim, A.A., Al-Nakeeb, Y., Lyons, M.Al-Hazzaa, H.M., Nevill, A., Collins, P.,Duncan, M. J. (2012). The prevalence of physical activity and sendentary behaviors relative to obesity among adolescents from Al-Ahsa, Saudi Arabia: Rural versus urban variation. J. of Nutr .and Metabol.: Article ID. 41: 75-89. 
- Al-Othaimeen, A. I. Al-Nozha, M., Osman, A. K.(2007). Obesity: an emerging problem in Saudi Arabia. Analysis of data from the National Nutrition Survey. East Med Health J. 13:441-448.

- American Heart Association.(2011). Understanding blood pressure readings 11 January 2011. Retrieved 30 March.

- Bellizzi, M.C., Dietz, W.H. (1999). Workshop and childhood obesity, summery of the discussion. Am. J. Clin. Nutr. 70 (1): 173S - 175S.

- Booth , J. (1977). A short history of blood pressure measurement. .Proceedings of the Royal Society of Medicine 70 (11): 793-9. PMC 1543468. PMID 341169.

- Calle, E. E. and Thun,M. J.(2004): Obesity and cancer. Oncogene 23, 6365 6378.

- Chobanian, A.V., Bakris, G.L. and Black, H.R. (2003). Seventh report of the Joint National Committee on Prevention, Detection, Evaluation, and Treatment of High Blood Pressure. Hypertension 42 (6): 1206-52.

- Dustan, H. P. (1991): Hypertension and obesity. Prim Care; 1991; 18: 495 - 507.

- El-Hamzmi MAF and Warsy, A. S.(1997): Prevalence of obesity in the Saudi population. Ann Saudi Med ; 17: 302 - 306.

- El-Hazmi, M. A. and Arjumand, S. W. (2001). Prevalence of hypertension in obese and non-obese Saudis, Saudi, Med. J.;Vol. 22 (1): 44- 48.

- Hays, N. P. (2006). Eating behavior and weight change in healthy postmenopausal women: results of a 4-year longitudinal study, Gerontol A boil Sci Med Sci 61: 608.

- Iman, M. S.(2007). The relation between food habits and slimness among Saudi Female students, Egypet. J. of Nutr. And Health Vol.2 No.1.

- Jee, S. H.; Sul, J. W. and Park J. (2006): Body- mass index and mortality in Korean men and women, N Engl J Med.; 355 : 779 - 87.

- Kannel, W. B. (2000): Fifty years of Framingham Study contributions to understanding hypertension. J Hum Hypertens; 14: 83 - 90.

- Kastarinen, M.J, Nissinen, A.M., Vartiainen ,E.A., Jousilahti, P.J., Korhonen, H.J. and Puska, P.M. (2000). Blood pressure levels and obesity trends in hypertensive and normotensive Finnish population from 1982 to 1997. J Hypertens , 18: 255. 262. 
- Katzmarzyk, P.T.; Jenssen, I. (2004). The economic costs associated with physical inactivity and obesity in Canada: An update. Can J App. Physiol, 29:90- 155.

- Khan, M. A. (2012). Desirable dietary patterns for health in Saudi Arabia, college of applied medical sciences, King Saudi University, P. O. Box 10219, Riyadh.

- Kuczmarski, R. J. , Ogden, C.L., Grummer-Strawnl, M., Flegal, K.M. and Wei, R. (2000). CDC growth charts; United States. Advanced Data from vital and health statistics No 314. Hyatts Ville, Maryland: National Center for Health Statistics.

- Licata, G., Scaglione, R. and Dominguez, L. J. (1999): Early markers of cardiovascular damage in obese subjects. Nutr Metab Cardiovas Dis; 9: 78-86.

- Mahan, L. K. and Escott-Stump, S. (2008). Krause's Food,Nutrition, and Diet Therapy, Saunders Elsevier. 12th Ed. Philadelphia: W,B. Saunders Co.Elsevier.

- Mahan, L. Kathleen (2000). Krause's Food, Nutrition \& Diet Therapy, 10th Ed. Philadelphia: W, B. Saunders Co.

- Mikhail, N., Golub, M. S. and Tuck, M. L. (1999): Obesity and hypertension. Pro Cardiovasc Dis; 42; 39 - 58.

- Musaiger, A. O. (2004). Overweight and obesity in the Eastern Mediterranean Region: can we control it? Eastern Mediterranean Health Journal. 10(6): 789.

- National Heart, Lung and Blood Institute. (2012). Calculate Your Body Mass Index. Retrieved 23 September.

- Park, J. E. and Park, E. (1979). Text book of prevention and social medicine 7th ed. Hessers barner side Ph Riblisher. 1268 Napier Town. Pp: 81.

- Rasheed, P. (1998). Perception of body weight and self-reported eating and exercise behavior among obese and non-obese women in Saudi Arabia. Public Health; 112 (6)409-14.

- Simopoulos, A.P. (1985). Fat intake, obesity, and cancer of the breast and endometrium. Med Oncol Tumor Pharmacother;2:125-35.

- SPSS. (1998). Statistical package for social science computer software, ver 16.0.

- Staessen, J.; Fagard, R. and Amery, A. (1998): Obesity and hypertension. Acta Cardiol Suppl ;29: 37- 44. 
- Tsugane, S., Sasaki, S. and Tsubono, Y. (2002). Under- and overweight impact on mortality among middleaged Japanese men and women: a 10-y follow-up of JPHC study cohort I. Int. J. Obse Relat Metab Disord 26, 529- 537.

- Wilson, P. E., D, Agostino, R. B. and Sullivan, L. (2002). Overweight and obesity as determinants of cardiovascular risk: the Framingham experience. Arch. Intern. Med. 162, 1867 - 1872.

- World Health Orgnization (2006). International malnutrition task of the international union of nutrition sciences. World Health Orgnization, Departement of Nutrition for health and development (NHD). Geneva Switzerland. 


\section{نقص الوزن والنمافة وعلاقتهم بالعادات الغذائية وضغط الدم \\ بين الطالبات السعوديات بجاهمة طيبة

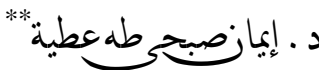 \\ د.}

الملخص العربى

مقدمة :

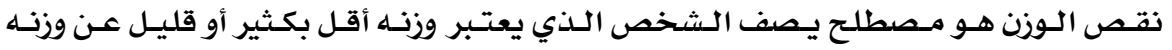

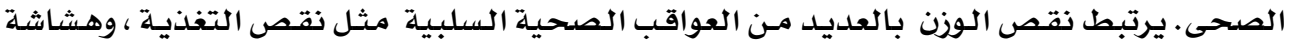

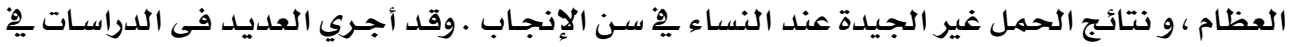

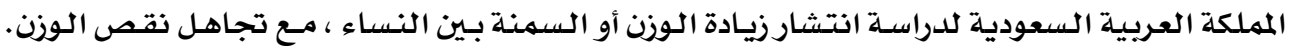

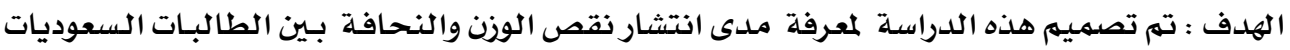

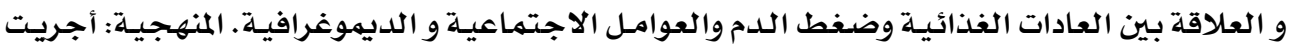

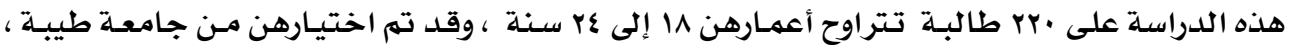

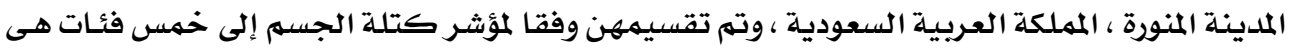

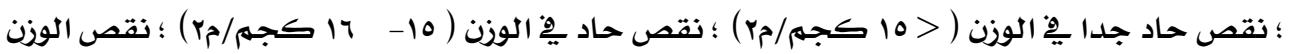

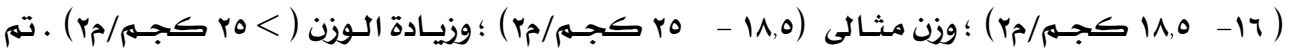

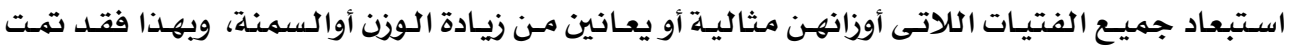

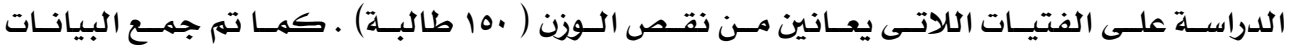

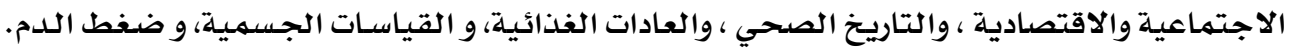

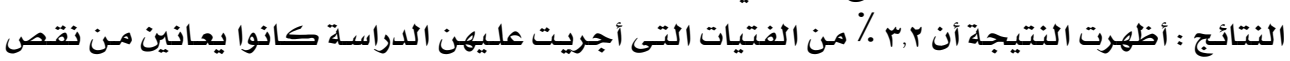

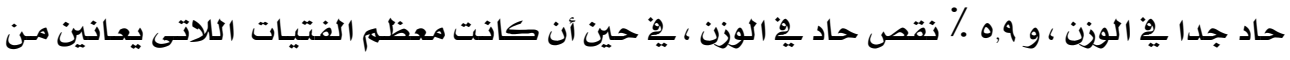

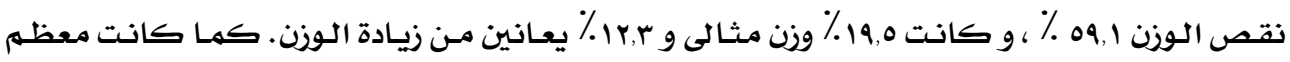

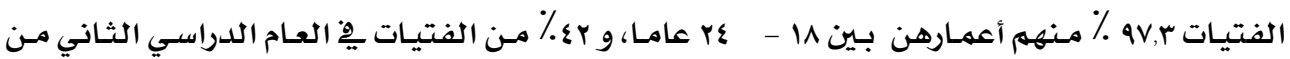

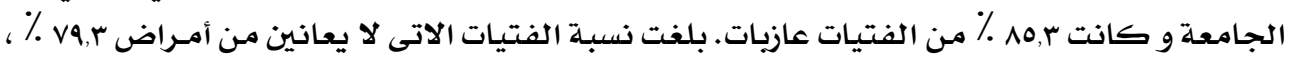

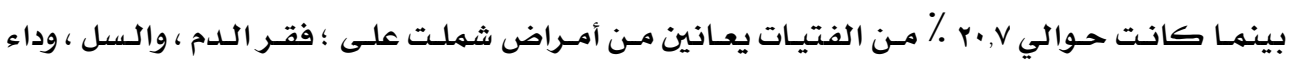

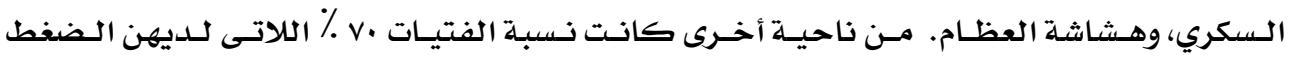

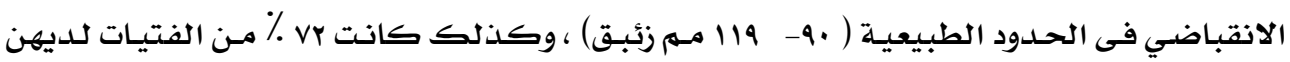

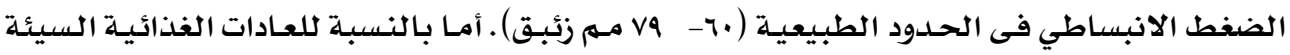

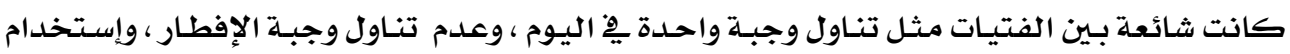

** قسه علوم الأغذية ، كلية علوم الأسرة ، جامعة طيبة، المملكة العربية السعودية.

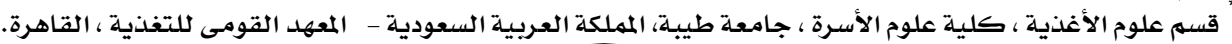




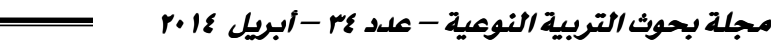

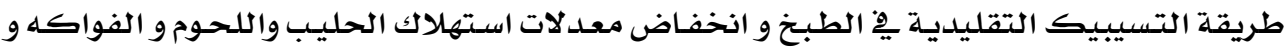

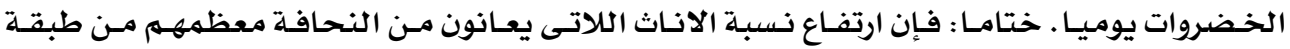

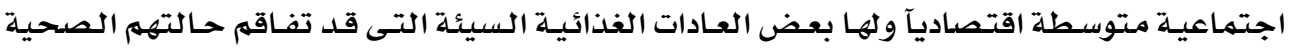

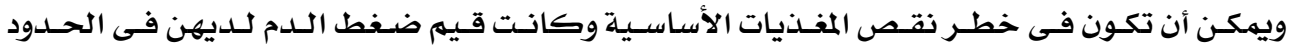

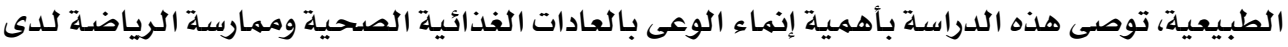
طالبـات الجامعة.

الكلمـات الدالـة (المفتاحيـة): نقـص الوزن، النحافة، ضغط الدـم، العـادات الغذائيسة، مؤثـر

كتلة الجسهم، الجامعـة، الطالبـات السعوديات. للمراسلة: drafaf@hotmail.com 